International Journal of Social Science And Human Research

ISSN(print): 2644-0679, ISSN(online): 2644-0695

Volume 05 Issue 03 March 2022

DOI: 10.47191/ijsshr/v5-i3-03, Impact factor-5.586

Page No: $739-744$

\title{
Implementation of the United Nations Peace Task Intermission for Indonesia Engineering Company Task (TNI)/Garuda Contingent XXXII-C from Haiti to Central Africa (2014-2015)
}

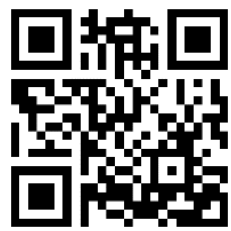

\author{
Roy Limbong ${ }^{1}$, Jonni Mahroza ${ }^{2}$, Triyoga Budi Prasetyo ${ }^{3}$ \\ 1,2,3 Indonesia Defense University
}

\begin{abstract}
Indonesia has potential in cooperation on the intermission of UN peacekeeping tasks, although the need for UN intermission does not occur frequently (incidentally), but it needs to be prepared in order to anticipate opportunities and challenges in the development of the situation in UN PKOs, as has happened to the Indonesian Armed Forces Engineer Company Taskforce/Garuda Contingent. XXXII-C, through a decision-making mechanism based on the UN Resolution in UN PKOs to carry out the intermission of peacekeeping tasks from Haiti to Central Africa (2014-2015). The Kizi Taskforce TNI/Konga XXXIIC/MINUSTAH or Konga XXXVII-A/MINUSCA, can complete their duties as UN peacekeepers on duty at the UN Mission in MINUSTAH - Haiti and carry out UN Peace Task Intermissions in MINUSCA, in order to prepare missions in the African Republic Center (CAR). On this "rare" opportunity, the UN intermission process can be carried out properly through effective diplomacy and negotiations, so that the TNI/Konga XXXII-C Kizi Taskforce can carry out tasks in two different missions at once. And on this occasion, the researcher tries to explore the data in the form of a research entitled "Implementation of the United Nations Peacekeeping Taskforce; Case Study of Intermission of Satga IEC/Konga XXXII-C from Haiti to Central Africa (2014-2015)", In this study, I tried to explain the mechanism and implementation of the UN peacekeeping mission, accompanied by various challenges and obstacles faced in the area of operation. as well as the steps and efforts taken to overcome them, so that the task of ending the mission of the IEC/Garuda contingent in Haiti and the reopening of the UN mission in the Central African Republic can take place safely and smoothly. The researcher explored this research, considering that this form of intermission assignment rarely occurs, not only in the IEC Taskforce/Garuda Contingent, but also in UN peacekeeping operations.
\end{abstract}

KEYWORDS: Strategy, Intermission, Decision Making, Conflict Resolution, Diplomacy.

\section{INTRODUCTION}

Assignment in two different missions in two different countries is not something that is commonly experienced by contingents who are members of UN missions. However, this quite rare experience happened to Taskforce IEC (Indonesia Engineering Company), which originally served in Haiti under the name of the Garuda Contingent (Konga) XXXIIC/MINUSTAH and then continued its duties to the Central

African Republic (CAR) under the name Konga XXXVIIA/MINUSCA. At the beginning of the assignment, the IEC, Konga XXXIIC/MINUSTAH Taskforce left for Haiti as the third Garuda contingent to carry out humanitarian tasks in the island nation of the Caribbean region. The existence of the

IEC Taskforce in Haiti was motivated by the earthquake that occurred in the country on January 12, 2010. An earthquake measuring 7 on the Richter scale not only destroyed existing buildings and infrastructure but also paralyzed the government in the country located in the Central America region. This resulted in an uncontrolled situation, increased crime, and a humanitarian crisis, which prompted the UN Security Council to give an additional mandate to MINUSTAH (Mission des Nations Unies pour la stabilization en Haiti) to carry out the recovery, reconstruction, and stabilization of Haiti. As a realization of this mandate, additional troops were added including the Garuda Contingent (Taskforce of Indonesia Engineering Company/IEC)) to assist Haiti's recovery efforts through the construction of infrastructure and public facilities that were damaged after the earthquake. However, as the political and security situation improves and the economy recovers in Haiti, on October 12, 2012, UNSC Resolution No. 2070 concerning the MINUSTAH consolidation plan marked by downsizing in the period 2013-2016. As a follow-up to the consolidation plan, in the period November 2013-June 2014, the first phase of reduction of military personnel was carried out by 1,249 people, including the IEC Taskforce which is scheduled to take place no later than April 30, 2014. 


\section{Implementation of the United Nations Peace Task Intermission for Indonesia Engineering Company Task (TNI)/Garuda Contingent XXXII-C from Haiti to Central Africa (2014-2015)}

Coinciding with the process of downsizing MINUSTAH, there was a sectarian conflict in the Central African Republic which prompted the United Nations to establish a multidimensional mission called MINUSCA (Mission multidimensionnelle integree des Nations Unies pour la stabilization en Republique centrafricane). In accordance with security council resolution number 2149 dated April 10, 2014, the establishment of MINUSCA aims to deal with sectarian conflicts that occur in the Central African Republic to achieve stabilization in all sectors in the country. This condition later became the momentum of the IEC Taskforce's intermission from Haiti to the Central African Republic. There are some special notes in the implementation of the IEC intermission from Haiti to the Central African Republic. First, the transfer of IEC duties is the first intermission of the Zeni contingent in peacekeeping operations. Although initially there were many debates related to the complexity and difficulties experienced in the field to move a contingent of Engineers to the accommodation with COE (Contingent Own Equipment) status and the amount of equipment they had, while the time allocation was limited; however, with careful planning and coordination along with the extraordinary work ethic of the troops, the IEC intermission process could take place smoothly and safely. Second, IEC started to enter CAR on May 21, 2014. Which means before the mission opened. This initially also caused a debate about the position and control of the IEC, considering that the FHQ (Force headquarter) and its components, including the Force Commander, did not yet exist, until the official mission was opened on September 15, 2014. However, with good coordination, IEC was then under the control of the TNI. Director of Mission Support (DMS). Third, after the opening of MINUSCA, the status of IEC was not only a military unit but also an enabling unit, so that command and administration were under the Force Commander but operationally (tasking authority) were more under the DMS. Fourth, the security situation in the Central African Republic (CAR) is so different from Haiti that it demands that the soldiers adapt immediately to these differences. This is indicated by the difference in the chapters of the $1945 \mathrm{UN}$ charter that apply, namely in Haiti, chapter VI applies, while in CAR, chapter VII is valid.

\section{THEORY AND CONCEPT}

\section{Strategy Theory}

According to Alfred Chandler (1962): Strategy is the setting of long-term goals and objectives of an organization, and the direction of action and allocation of resources needed to achieve these goals and objectives. In this article, the author formulates an intermission strategy that can be formulated, namely the realization of the goals (ends) "to achieve certainty in the timing of intermission, the responsibility for redeployment the troop and materials as well as the fulfilment of the material requirement according Spesification of Units Requirement", by the ways of "implementing diplomacy and effective negotiations, using the strength (means) of the "Permanent Mission of the Republic of Indonesia (PTRI) in New York, Ministry of Foreign Affairs staff, and Indonesia Peace and Security Center (IPSC), and the IEC Taskforce (CBM/Trust and Military Capability)", supported by infrastructure with equipment/materials that are ready for operation on the next mission.

\section{UN- Intermission Concept}

Inter-mission or in its official term called Inter-mission cooperation is a new concept that is being developed by the United Nations in the context of conflict resolution through the transfer of capabilities/resources from one mission to another, to achieve effectiveness and efficiency of the implementation of peacekeeping operations. The concept which was officially introduced in December 2012 is considered important to be developed immediately considering the increasing intensity of the conflict, while budget support for peacekeeping operations is decreasing due to the global economic crisis. Initially, inter-missions were carried out in the form of intermission capabilities/resources in the form of personnel, equipment, and funds from one mission to another in one region/sub-region, for example, the transfer of helicopters from Liberia to Côte d'Ivoire when it happened. the post-election crisis in 2011. However, in subsequent developments, the implementation of the intermission became more complex in the form of intermission contingents from one region to another, as happened to IEC, intermission inter-region from America to Africa.

\section{Decision-Making Concept}

According to Snyder, the definition of decision-making theory which assumes that through decision making theory will know the behavior of the State in international relations. In carrying out its duties, the United Nations has several specialized organizations and agencies engaged in certain fields, such as WHO (health), FAO (food and agriculture), IMO (maritime), and so on. The United Nations itself was founded on October 24, 1945. Its official name is United Nations, commonly abbreviated as UN. The main objectives of the United Nations are:

1. Maintaining world peace and security

2. Promote and encourage brotherly relations between nations through respect for human rights,

3. Fostering international cooperation in economic, social, cultural, and environmental development,

4. To become the center of synchronization of all joint actions against countries that endanger world peace,

5. Provide humanitarian assistance in case of famine, natural disasters, and armed conflict. 


\section{Implementation of the United Nations Peace Task Intermission for Indonesia Engineering Company Task (TNI)/Garuda Contingent XXXII-C from Haiti to Central Africa (2014-2015)}

According to the United Nations, peacekeeping is a technique designed to maintain peace when conflict subsides and to help implement agreements agreed upon by peacemakers and create conditions for lasting peace (United Nations Peacekeeping, "What Is Peacekeeping?", http://www.un.org/en/peacekeeping/operations/peacekeepin

g.shtml). There is an understanding between the objectives of the PKOs and the Indonesian national interest in international relations as stated in the Preamble to the 1945 Constitution of the Republic of Indonesia as the constitutional basis, namely: "to participate in carrying out world order based on independence, eternal peace and social justice". The UN's critical need in preparing a mission in Central Africa is manifested in UN Security Council Resolution No. 2149 dated April 10, 2014 regarding the granting of the MINUSCA Mandate in the Central African Republic. (Resolution no. 2149, Mandates September 15,2014 as Date for Transfer of Authority) as the momentum for the intermission of the IEC/Konga XXXII-C Taskforce from Haiti to Central Africa (2014-2015). The Decision making to implementation of the interests of international relations is manifested in the involvement of sending peacekeeping troops under the banner of the United Nations. So that the State of Indonesia remains consistent with a free and active foreign policy, namely Indonesia is free to determine attitudes and policies towards international problems and does not bind itself in priority to any world powers. Simultaneously, Indonesia also actively participates in resolving conflicts, disputes, and other world problems as the goal of independence, lasting peace, and social justice. As in the UN mission, in the absence of partiality or impartiality towards one of the conflicting parties (conflict), but actively seeking peace efforts in every conflict and socializing that colonialism in the world must be abolished because it is not in accordance with humanity and justice.

\section{Emergence of the Idea for Conflict Resolution}

Conflict is a struggle between opponents over values and claims to scarce status, power and resources (Coser;1956). The basis of a conflict resolution, is an understanding of the conflict itself. First, the most important thing to analyze are some kinds and reasons why conflicts occur, even in everyday life. Conflict has existed since the presence of humans on earth, because of the many differences that humans have, causing differences in understanding where differences in understanding are themselves conflicts of interest between individuals. Several types of destructive conflict are conflicts that are civil wars (between 2 groups within a country), or when a conflict has entered a violent stage, such as the sectarian conflict that occurred in CAR, is evidence of the failure of the government leadership in carrying out its duties to protect all its citizens from divisions and conflicts that lead to violence that takes many victims and has a negative impact on the CAR economy, especially the declining welfare of the country. According to Dahrendorf conflict is defined as a situation that occurs as a result of the pressure that surrounds decisions in several choices, which is sometimes manifested through confrontation between parties. Conflict resolution is an individual or group's way of resolving a problem that is being faced with another individual or other group voluntarily. conflict resolution also recommends using more democratic and constructive ways to resolve conflicts by giving conflict parties the opportunity to solve their problems by themselves or by engaging wise, neutral, and fair third parties to help conflicting parties resolve the issue. (conflict-prevention) are interventions to stop violent conflicts (peacekeeping) through negotiations to create peace (peace-making) with fostering peace in order to survive in the long term (peace-building).

\section{DEFENSE DIPLOMACY TO EFFECTIVE DIPLOMACY AND N EGOTIATION IN CONFIDENCE BUILDING MEASURES (CBMS)}

Defense diplomacy is an activity of state cooperation, both multilaterally and bilaterally, carried out by the military and related stakeholders in peacetime by involving military cooperation on strategic issues, ranging from the military role to non-military roles, such as the existence of a peacekeeping force, security enforcement (peace enforcement), promotion of good-governance, disaster response, protecting human rights, etc. Negotiation as one of the diplomatic functions according to the 1961 Vienna Convention, can prevent or eliminate conflict. The success of negotiations can be influenced by internal factors and external factors of the negotiating countries. Based on consideration of the factors that affect the country, so that a government has a different way of reading these factors so that there is a reorientation of foreign policy. This reorientation of foreign policy affects all foreign policies of a country during the reorientation government (Holsti, 2016). Thus, the main element of diplomacy is negotiation and is carried out to fight for the interests of the state. Diplomatic activities are carried out in the context of fighting for the national interest as far as possible through peaceful means. Therefore, efforts to maintain peace are a diplomatic priority as long as it does not damage the national interest which is the goal of diplomacy.

One of the most difficult times in implementing this intermission is waiting for the Indonesian government's decision regarding the status of the Taskforce, whether to return to the country or continue the task to a new mission area. On the one hand, the decision regarding the repatriation schedule for Indonesia Engineering Company (IEC) had been determined by UNDPKO before we arrived in Haiti, namely April 30, 2014, on the other hand, the IEC Taskforce was prepared to carry out tasks for one year, namely until November 2014. The option of moving to another area The new mission was the best alternative at that time to continue the TNI's kizi term of service in addition to carrying out constitutional orders, as stated in the 4th Paragraph of the Preamble to the 1945 Constitution of the Republic of Indonesia, namely "to participate in carrying out world order based on independence, eternal peace 


\section{Implementation of the United Nations Peace Task Intermission for Indonesia Engineering Company Task (TNI)/Garuda Contingent XXXII-C from Haiti to Central Africa (2014-2015)}

and social justice." , as well as a solution to the limitations of human and material resources as well as accelerating the operational preparation of the UN Taskforce and budget savings to deal with the rise of conflicts in the dynamics of inter-regional strategic environment development effectively and efficiently, as well as supporting the policy of the President of the Republic of Indonesia, to achieve 4000 peacekeepers. Furthermore, according to the leadership's policy, the Central African Republic became the next mission area for the IEC Taskforce to continue their duties. However, there are 3 (three) main problems in realizing the IEC intermission plan from Haiti to the Central African Republic, namely First, the certainty of the timing of the intermission which did not come. Second, the responsibility for material transfer outside the MoU is unclear, and third, the difference in requirements that is quite striking on the needs of the Engineer Company between MINUSTAH (Haiti) and MINUSCA (CAR). In short, the three main problems can finally be solved through an effective diplomatic and negotiation process in increasing trust and building capacity in UN Inter-mission for PKOs.

\section{Diplomacy and Negotiations in the face of uncertainty about the timing of the inter-mission.}

Starting with the working visit of IPSC Commander and staf of Permanent Mission of the Republic of Indonesia to Haiti on January 23-27, 2014, the diplomatic process in order to move IEC from Haiti to CAR began. During the working visit, IPSC Commander and his entourage had the opportunity to carry out a courtesy call to the SRSG and the Force Commander - MINUSTAH as well as to convey the plan to transfer IEC from Haiti to CAR, whose implementation has yet to be determined, awaiting a resolution regarding the handling of conflicts in CAR. However, until the end of March 2014, there was still no decision regarding the opening of a UN mission in order to deal with the conflict in CAR so that MINUSTAH decided that IEC's assignment in Haiti would still end (as planned) on April 30, 2014, and as of April 9, 2014, it had been in progress. cease of operation position to prepare for repatriation. MINUSTAH's decision is based on the reason that the PBB takes a minimum of 1 (one) month to carry out the auction up to the contract, both ships and planes to transport the personnel and materials of the Taskforce. Although the resolution on CAR has been issued on April 10, 2014, the issue regarding the certainty of the timing of the IEC intermission is still not resolved. This is because the UN Mission in CAR will only open on September 15, 2014, and the official approval of the Indonesian government regarding the redeployment of the task of Indonesia Engineering Company (IEC) from Haiti to CAR has not come out until the deadline determined by UNDPKO. Facing this situation, we communicated with Military Advisor, which was followed up by communication to the Ministry of Foreign Affairs, so that on April 30, 2014 the Verbal Note

No.S/078/PM/202/IV/2014 was issued regarding the approval of the Government of the Republic of Indonesia. to transfer the task of IEC Konga XXII-C/MINUSTAH from Haiti to the Central African Republic (MINUSCA). Based on the verbal note, the plan to transfer the Taskforce IEC can be realized.

\section{Diplomacy and Negotiation in dealing with responsibilities of material transfer outside the MoU.}

The next problem that arises is, as stated in the MoU, the UN party (in this case Movcon) is only responsible for transporting all COE personnel and materials according to the amount stated in the MoU with a maximum tolerance limit of $10 \%$, other than this, it is fully returned to TCC; and in fact the material of the Taskforce far exceeds these provisions. According to the MoU, there are 27 containers of goods belonging to the Taskforce which are categorized as major equipments to transport the Taskforce's selfsustainment materials. Meanwhile, to transport all Taskforce materials (including prefabricated structures with COE status), \pm 52 containers are needed. The fulfillment of the shortage of 27 containers and the cost of transporting the additional containers will be fully borne by TCC. To the TCC, we have tried to report this to the IPSC, but no solution has been given while we continue to be urged to meet the repatriation schedule set. Various alternative solutions continue to be pursued by the Taskforce, including negotiating with MINUSTAH. Various paths were explored starting from regional MINUSTAH in Gonaives, Supply Section, Movcon, JLOC to Mission Support. During the negotiation process, we always communicate and report any developments to Permanent Mission of the Republic of Indonesia, so that it can be followed up at the UNHQ level because every outcome of our negotiations with MINUSTAH must obtain approval from UNHQ according to the relevant field. Furthermore, with the approval of the Permanent Mission of the Republic of Indonesia, then the Taskforce submits additional containers to MINUSTAH (in this case through the Director of Mission Support) with costs (container prices and shipping) that will be deducted from the reimbursement. However, with the issuance of the Indonesian government's decision to approve the transfer of the Taskforce to MINUSCA, 20 additional container support from MINUSTAH has become a loan which is regulated in the asset transfer mechanism in the context of transmission, the delivery of which is also the full responsibility of the United Nations.

\section{Diplomacy and Negotiation in dealing with different requirements between MINUSTAH (Haiti) and MINUSCA (CAR).}

The dispatch of the Taskforce to a mission is based on the MoU whose contents are adjusted to the Statement of Units Requirements (SUR) that has been set for the mission. Given that each mission area has different characteristics and task challenges, the requirements set are not always the same. This is also a problem in shifting the task of IEC considering that the mission of MINUSTAH (Haiti) is stabilizing and humanitarian (as regulated in chapter VI of the UN charter) while MINUSCA (CAR) is peace enforcing (as regulated in chapter VII). The types and quantities of materials owned by the Taskforce are different from those specified in the requirements for the company's engineers at MINUSCA, in addition to the condition of the vehicles and equipment 


\section{Implementation of the United Nations Peace Task Intermission for Indonesia Engineering Company Task (TNI)/Garuda Contingent XXXII-C from Haiti to Central Africa (2014-2015)}

that are no longer new. Facing these problems, negotiations and diplomacy efforts were carried out with the aim of convincing the parties involved in the MoU negotiations to fully accept the Taskforce' material / COE and if necessary adjustments to the SUR, only need to add some equipment. In dealing with this situation, we benefited from the COE post inspection report which showed that the material condition of the Taskforce was almost $100 \%$ so that, although not new, it was considered feasible to be sent again to the new mission area. The second advantage is the lack of local contractors who have engineering skills in CAR, so the need for a contingent of engineers is very urgent to prepare for the opening of the mission. The third advantage is that we are the first engineer contingent to serve in CAR, so it is our input that ultimately becomes the refinement of the engineer contingent's SUR at MINUSCA.

\section{RESEARCH METHOD}

This journal uses a eksplanative-qualitative method. Sources of data obtained consist of primary and secondary sources obtained in the form of narrative data, descriptions and not numbers. The primary data in this study are the results of interviews with related institutions such as the Ministry of Defense, TNI Headquarters and Headquarters. While secondary data is data obtained indirectly from the source where this is taken from additional data that can help researchers such as books, articles in magazines or newspapers, and internet sites. These data are data related to the handling of transnational crimes at the sea borders of Indonesia, Malaysia and the Philippines.

\section{DISCUSS}

The shift in the global center of gravity (global center of gravity shifting) from west to east, has resulted in the development of a dynamic global strategic environment, so that it can affect the inter-regional, regional and national environment, as is a world order, where threats spread with uncertainty, where conflict is an unpredictable part and where the ability to maintain and support national interests is limited by constraints, both material resources and human resources and budgets due to the global economic crisis. Then the intermission strategy of the IEC/Konga Taskforce from Haiti to Central Africa in support of Indonesia's defense diplomacy as a form of increasing "trust" (CBMs) for world peace under the banner of the United Nations. ensure peace for the world. The importance of the readiness of the TNI / IEC Taskforce by increasing trust through CBMs in assisting and supporting the goals of the United Nations, especially in realizing peace to face problems in UN peacekeeping operations (PKOs). Furthermore, in addition to CBMs related to the challenges of the inter-mission process, it is also necessary to increase capacity in trust building and fostering the character of the peacekeepers themselves which have been embedded in the identity of the Indonesian nation with the ideology of Pancasila as a strategic power center that has been believed to be true, since seizing and defending independence until now. Facing with the dynamics of PKOs regarding intermissions with different situations (different chapters) being a fairly complicated obstacle, so that it is also necessary to increase the ability of the Taskforce in adjusting to different situations from the previous mission, the response and attitude of Indonesian defense diplomacy and the readiness of the TNI/IEC taskforce in dealing with intermissions should be formulated systematically, holistically and integrally as a manifestation and role of the TNI/IEC Taskforce in realizing national interests in the interests of international relations, namely carrying out main tasks in accordance with the constitutional basis in the mandate of the opening of the 1945 Constitution in the 4th paragraph... "participate in a world order based on freedom, lasting peace and social justice".

\section{CONCLUSIONS}

In UN Peacekeeping operations (PKOs), inter-mission is a strategy which needed to accelerate the handling of global, regional and inter-regional conflicts to prevent more victims and conflicts that will become more widespread as well as the existence of "Limited Human Resources and Materials as well as acceleration of the operational preparation of the UN Taskforce and budget savings. , to respond for the increasing number of conflicts in the dynamics of the development of the inter-regional strategic environment by effectively and efficiently. As the implementation of Indonesia Engineering Company (IEC) inter-mission from Haiti to CAR is tangible evidence, Inter-mission process can run smoothly. From the UN's point of view, this is very beneficial in terms of the speed with which the mission is set up as well as being able to make effective use of the budget to facilitate logistical support. Meanwhile, from the Indonesian government's perspective, this also facilitates the process of dispatching contingents to new mission areas, given the bureaucracy that is not too complicated in its implementation. This is of course if the Taskforce that will carry out the intermission has mandates, duties and responsibilities with the same nature and character as the previous mission. Like the Taskforce IEC/ Konga XXXII-C/MINUSTAH Taskforce which carried out the intermission, it became the Taskforce IEC/ Konga XXXVII-A/MINUSCA Taskforce as a Taskforce that focuses on the implementation of engineering tasks. Intermission will become very complex and difficult to implement if the unit changes its function in terms of its mandate, duties and responsibilities.

Thus, the biggest challenge faced in its implementation was the certainty of time and an agreement that did not come immediately, resulting in the contingent having experienced various difficulties, especially related to logistical support from the mission and maintaining the morale of soldiers, both in capacity building of soldiers and facing different situations (Chapter VI to Chapter VII). 


\section{Implementation of the United Nations Peace Task Intermission for Indonesia Engineering Company Task (TNI)/Garuda Contingent XXXII-C from Haiti to Central Africa (2014-2015)}

Other challenges that arise are related to the security situation, health problems, and of course logistical support, especially in the context of mission transfers and for the establishment of camps in new areas. In the end, I hope this simple article can be useful in order to support the preparation of the next UN contingents, especially when facing the task of UN intermission in Peacekeeping Operations (PKOs).

\section{REFERENCES}

\section{Book}

1) Barston, R.P. Modern Diplomacy. Longman. N.Y, 1997.

2) Boutelis and Smith, The Critical Role of Engineers in UN Peacekeeping, International Peace institute, Vienna, 2014.

3) Creswell, John W. Qualitative Inquiry and Research Design: Choosing among the Five Approaches in Creswell, John W. Research Design Qualitative, Quantitative and Mixed Approaches. Third Edition. Student Library. Yogyakarta, 2010.

4) Cottey, A., \& Forster, A. (2004). Reshaping Defense Diplomacy: New Roles for Military Cooperation and Assistance. Oxon: Routledge.

5) Ghosh, Peu. International Relations, Second Edition. PHI Learning Private Limited. New Delhi, 2011.

6) Holsti, K.J. International Politics: A Framework for Analysis, translated by Azhary, M. Tahir, International Politics: Framework for Analysis, Volume 1. Guidelines for Science Jaya. Jakarta, 1987.

7) Hough, Peter. Understanding Global Security. Routledge Taylor and Francis Group. London and New Yourk, 2004.

8) Morgenthau, Hans J. Politics Among Nations, The Struggle for Power and Peace, revised by Thompson, Kenneth W., translated by Maimoen, S., Fatwan, A. M., and Sudrajat, Cecep, Politics between Nations, Ed. 1., Cet. 1. Indonesian Torch Library Foundation. Jakarta, 2010.

9) Perwita, Anak Agung Banyu and Yani, Yanyan Mochamad. Introduction to International Relations, cet. 3. PT Youth Rosdakarya. Bandung, 2011.

10) Roy, S.L. Diplomacy, translated by Herwanto and Mirsawati. CV. Rajawali., Jakarta, 1991.

11) Sugiyono, (2012). “Quantitative, Qualitative, and R\&D Research Methods. 17th edition". Bandung: Alphabeta 2012

\section{Constitution}

1) Mandate of the opening of the 1945 Constitution in the 4th paragraph... "participatein a world order based on freedom, lasting peace and social justice".

\section{Journal}

1) Winger, G. (2014). The Velvet Gauntlet: A Theory of Defense Diplomacy What Is Defense Diplomacy? In A. Lisiak \& N. Smolenski (Eds.), What Do Ideas Do? (pp. 1-15). IWM Junior Visiting Fellows' Conferences.

\section{Website}

1) https://employers.glints.id/resources/mengenal-vuca-volatility-uncertainty-complexity-ambiguity/

2) http://www.un.org/en/peacekeeping/operations/peacekeeping.shtml). (United Nations Peacekeeping, "What Is Peacekeeping?)

3) http://www.whatsinblue.org/2012/12/peacekeeping-and-inter-mission cooperation-briefing.php 